\title{
Lactose Unit
}

National Cancer Institute

\section{Source}

National Cancer Institute. Lactose Unit. NCI Thesaurus. Code C73565.

A unit of measurement for the activity of lactase enzyme which is expressed as the amount of enzyme that hydrolyzes one microequivalent (uEq) of galactosidic linkage per one minute at a pH of 4.5 and at 37 degrees Celsius. 